\title{
A Model for Assessing the Level of Tourism Impacts and Sustainability of Coastal Cities
}

\author{
Beser Oktay Vehbi \\ Eastern Mediterranean University, Faculty of Architecture, \\ Department of Architecture, North Cyprus, \\ Turkey
}

\section{Introduction}

Over the last century, tourism has became one of the fastest growing industries in the world and current trends and tendencies indicate that it could become the most important sector in terms of international trading in the 21 $1^{\text {st }}$ century. Most governments encourage tourism because of its ability to increase and spread economic development thus reducing the inequalities in income distribution by providing and creating employment opportunities (Pearce, 1989; Coccossis \& Parpairis, 1995; Wahab \& Pigram, 1997). Nevertheless, the development of tourism, which is dependent upon the attractive features of the primary resources of destinations, particularly over the last decade, has raised many questions concerning the physical and social destruction of those resources, which initially attracted tourists. Although it has led to an enormous increase in investment and employment, the tourism industry may become a threat if not managed appropriately (Calvia Declaration on Tourism, 1997).

It is obvious that a fundamental relationship exists between the environment and tourism. The environment, natural or built, is the most fundamental ingredient for tourism development. The natural environment is that which exists in nature such as the climate and weather, the landscape and its topography, water features and the ecological systems. The built environment is comprised of physical features that are mainly all types of buildings, infrastructural development, as well as archeological and historical sites (Inskeep, 1991, p. 339). As Inskeep (1991) indicates, there are three aspects of the tourism-environment relationship, these are;

- Many features of the physical environment are consistently to be attractions for tourists,

- Tourism facilities and the infrastructure constitute all aspects of the built environment,

- Tourism development and tourist use of an area generates an environmental impact.

Considering the above arguments, the development of tourism is highly dependent on the availability and the type of attractive natural and/or built resources in an area, which tourists demand, expect and pay for. In many coastal cities, particularly, the natural, unspoiled scenery, beaches, mountains, ancient monuments, traditional, historical, picturesque towns and villages and many more factors constitute the primary factors in creating a successful tourism industry. A specific type of tourism development of an area 
(e.g. beach resort, ski resort, etc.) depends primarily on the nature of areas environmental resources.

However, coastal areas are faced with increasing pressures of development, particularly tourism development, and are also more likely to be faced with increasing challenges with regard to their environmental protection (Coccossis \& Parpairis, 1995). The increasing amount of tourism development erodes the environmental resources on which it depends. On the other hand, tourism has the potential to create beneficial effects on the environment by contributing to environmental protection and conservation. It is a way to raise awareness of environmental values and it can serve as a tool to finance protection of natural areas and increase their economic importance.

In order to prevent these haphazard development and negative impacts, tourism need to be ecologically acceptable in the long term and financially viable and fair from a social and ethical for local communities (UNEP \& WTO,1998, p: 1). In other words, it must be sustainable. According to one of the sustainable tourism definition, tourism must become part of the natural, cultural and human environment, respecting the balance that is characteristic of many coastal cities. Also it is economically viable but does not destroy the resources on which the future of tourism will depend, notably the physical environment and the social structure of the host community (Swarbrooke, 1998, p: 14).

With these initial discussion points in mind, the aim of this study is to develop a model for assessing the level of impacts of tourism on the physical, economic and social environments in coastal cities and to determine relationship beween tourism impacts and sustainable tourism indicators. With this aim in mind, the study first reviews the positive and negative impacts of tourism on the physical, economic and social environments of the coastal cities. In the second part, the relationship between tourism and sustainability, sustainable tourism is discussed. Then, the sustainability indicators, their selections and scaling methods which are essential for assessing impacts of tourism, are explained. In the fourth part, the model for measuring and assessing the level of tourism impacts and its sustainability in coastal cities is presented. Finally, a general conclusion is presented to summarize all the arguments of the study.

\subsection{Tourism impacts}

The effects resulting from tourism have appeared clearly and more perceived in the coastal cities. Generally, tourism impacts, which become different according to countries or regions, may be classified in three titles; economic, socio-cultural and physical (natural and built). Moreover, these titles may respectively display positive and negative features.

The tourism impacts on the physical environment are associated with the interferences with to the natural, cultural or historical resources, which may be reflected as the development of tourist service facilities, the preservation of historic and cultural resources, the provision of recreation opportunities for visitors and residents, better roads and public facilities (Davis et al., 1988; Gartner, 1996; Liu \& Var, 1986; Milman \& Pizam, 1988; Murphy, 1985).

\subsubsection{Physical environment (Natural and built environment)}

Natural areas form the very basis of many tourist attractions by highlighting the scenic value or exceptional encounters with fauna and/or flora. Tourism activities affect the 
natural environment in various ways and some forms of tourism can be extremely detrimental to ecologically sensitive areas, resulting in habitat degeneration or destruction. It can cause the deterioration of green fields, pollution of sea water as well as air and noise pollution. However, it may also call for the conservation of natural green areas and an improvement in the quality of the environment.

In general, the built environment in tourist areas includes densely populated centers as well as the ruins of past settlements. Tourism was not the initial factor in the development of these built environments, but it exerts a powerful influence in the patterns of the daily life in such environments (Gartner, 1996). Tourism may create a positive as well as a negative impact at significant levels in those areas where the built environment is the major tourist attraction in terms of its age, aesthetic appearance and historical interest.

The size and intensity of tourism development and the associated urbanization of the coastline, the production of industrial wastes and the generation of pollution together with insufficient planning controls, are the primary causes of environmental degradation and transformation in the built environment of the coastal cities. The pattern of the expansion of tourism functions depends on the nature of the surrounding topography, the transportation network and the existence and enforcement of planning regulations and restrictions (Matheison \& Wall, 1982, p.120).

Conservation of the historical and cultural heritage, preservation of the traditional buildings as well as the enhancement of the environment and the restoration of the old fabric together with the adaptation thereof to meet the requirements of contemporary life are positive impacts of tourism in the built environment (Inskeep, 1991, p.342; Ashworth \& Goodal, 1990; Matheison \& Wall, 1982, p.98-99). In addition to this, the increase in the number of tourists may encourage the development of an infrastructure such as transport, road maintenance, organizing parking areas and the provisions of water and electricity in peak seasons.

There is no doubt that, tourist increase the challenge of managing sustainable resources. Large number of tourists may be a threat for these resources. Because, in peak periods of the year tourist numbers often double the islands population and this situation also leads to (Mathieveson \& Wall, 1982, p: 118):

- Overcrowding increasing pressure on the natural resource environment including demands for service provision such as water.

- Over-development of the built environment create pressure on the service facilities and infrastructure development,

- Pollution from sources causes degradation and overuse of the natural environment.

Another spatial effect by tourism development is the second-home development, especially which emerges on coastal areas. By means of the rapid development of these second homes the region becomes the core for tourism development. Moreover, the possession of the agricultural and olive-tree lands, start to change owners and are open for building.

Main positive indicators of the tourism on physical environments are increased environmental consciousness, improving the beauty of the environmental landscape and protection of local architecture. Moreover, these can be added as to contributing to positive consequences (UN, 2001, p: 8): 
- Encouraging the environment awareness of local people and business to use environment protection programs.

- Supporting the maintenance and improvement of natural heritage and ensuring its conservation for present and future use.

- $\quad$ Better usage of the environment.

- Providing economic incentive pay for investment in water quality or beaches.

The environmental changes resulting from tourism not only include the features of natural structures, but also historical and architectural heritages of the area. Thus, during the tourism development, these heritages may be damaged or harmed. In this context, no protection of the characteristics of local architecture seen as protected in new developing areas are underlined as different important problems. In other words, tourism negatively causes the demolition of the traditional townscapes in order to accommodate the tourism industry (Ashworth \& Goodal, 1990). Tourist facilities, such as- restaurants, cafes and second homes, can alter the local identity and affect the physical appearance of the coastal cities, in a negative manner. Some of the visual pollution caused by tourism can be summarized as follows (Inskeep, 1991, p. 345):

- Poorly-designed hotels and other tourist facility buildings that are not compatible with the local architectural style and scale or integrated into the natural environment;

- Use of inappropriate building materials on external surfaces;

- Badly planned layout of the tourist facilities;

- Obstruction of scenic views by development.

\subsubsection{Economic environment}

Tourism development has both positive and negative impacts on the economy of coastal cities as well as on their countries as a whole. Tourism offers opportunities for the development of leisure activities, cultural awareness and international exchanges as well as providing employment and income in the coastal towns (Coccossis \& Parpairis, 1995, p.2).

The economic impacts of tourism on an area can be understood at two different levels- the national level and the local level. At national level the most publicized effect of foreign tourism is its ability to generate foreign exchange and thus contribute positively to the country's balance of payment. At a local level, job creation or the reduction of unemployment has been identified as one of the most prominent benefits of tourism development. Economic gain, an increased standard of living (Milman \& Pizam,1988), income re-distribution for hosts and government (Perdue et al., 1987), the price of goods and services (Johnson et al., 1994); the cost of land and housing (Perdue et al., 1987), the cost of living, the development and maintenance of the infrastructure and resources are other examples of the economic impacts of tourism development. In addition, the positive economic impact of tourism may contribute towards, or even provide much needed funds for preserving the historic and / or natural environment and the cultural heritage of the local environments.

However, tourism may create undesired negative effects such as over-dependence on the tourism sector, increased inflation and higher values, increased amount of import (labor or goods), seasonality of production and so low rate of return on investment and creation of other costs such as garbage collection and disposal (UN, 2001, p: 7). 


\subsubsection{Social environment}

Whereas economic and environmental indicators of tourism do lend themselves to objective measurement, the socio-cultural impacts are often highly qualitative and subjective in nature (Cooper et al., 1998). According to Gartner (1996), most jobs which are available for local people in the tourist industry, such as servants, housemaids, waiters, gardeners and other menial work may make people feel inferior. In addition to this, the inhabitants may lose their jobs on account of the seasonality of such works in these areas. Tourism also creates cultural exchange opportunities and more recreational facilities, but it can also cause disruption to various quality of life factors. In other words, tourism creates opportunity for locals to learn and share the cultural traditions and aspects of the tourist's indigenous culture and heritage, whilst also giving rise for concern. As has already been stated, information gathered from the literature, reveals and confirms that tourism can lead to the improvement of local public services (Keogh, 1990), increased cultural activity (McCool \& Martin, 1994), and the alteration to some aspects of traditional culture (Akis et al., 1996). Conversely, careful and monitored tourism can also led to the re-ceration and preservation of the identity of local culture (Liu and Var, 1986). However, the social and cultural impacts of tourism development could negatively affect the perception of residents (Jurowski et al., 1997; Liu \& Var, 1986; Milman \& Pizam, 1988; Perdue et al., 1987). In addition to this, the influence of tourists can cause young people to become involved in bad habits. It can also create a degree of apathy (Doxey, 1976) between tourists and locals as a result of different and perhaps unexpected behaviour and the obvious wealth of the tourists. Congestion, traffic jams, noise and increasing crime are some examples of the socio-cultural impacts of tourism (Gunn, 1988; Johnson et al., 1994; Milman \& Pizam, 1988).

\section{Sustainable tourism}

There are many definitions available for tourism and sometimes it's difficult to give the most correct explanation. Basically, tourism is a movement in space from a person's home district to one or more destinations and then back again in a certain period.

Sustainability is about meeting basic human needs and wants. People value their health, economic security and happiness and that of their children. These are primary elements in relation to the issue of quality of life. Sustainability refers to "long-term economic, environmental, and community health" (Bauen et al., 1996, p. 4). According to Bauen et al. (1996), it was suggested that researching and identifying new ways of creating economic vitality, maintaining a healthy environment and building healthy communities and meeting local needs.

The Brundtland Report (WCED, 1987) formulated the well-known definition of sustainable development as, "sustainable development is development that meets the needs of present generations without compromising the ability of future generations to meet their own needs". Sustainable tourism, is a kind of development model, which administrates all of the resources for the economic, social and aesthetical needs of locals and visitors and prove the same conditions for future generations and meets their needs while protecting the artificialnatural environment and cultural wholeness, proving the continuity of the ecological process, the biological variety; and the life systems, without any changes (WTO, 1998, p: 32). 
There are many available definitions about sustainable tourism but there is not any commonly accepted one. According to WTO, sustainable tourism development meets the needs of present tourists and host regions while protecting and enhancing opportunities for the future. It is very important management of all resources in such a way that economic and social needs can be fulfilled while maintaining cultural integrity, essential ecological process, biological diversity and life support systems (WTO, 1993, p: 10).

In general, many definitions of sustainable tourism emphasize the environmental, social and economic elements of the tourism system. For instance, sustainable tourism means the tourism which is economically viable but does not destroy the resources on which the future of tourism will depend, notably the physical environment and the social structure of the host community (Swarbrooke, 1998, p: 14). Also, the policy of sustainable tourism development refers to tourism as being ecologically acceptable in the long term and financially viable and fair from a social and ethical viewpoint for local communities (Rogers \& Collins, 2001). Thus, tourism must become part of the natural, cultural and human environment, respecting the balance that is characteristic of many holiday destinations particularly of small islands. Sustainable tourism also emphasizes on conserving the cultural heritage and traditions of local communities.

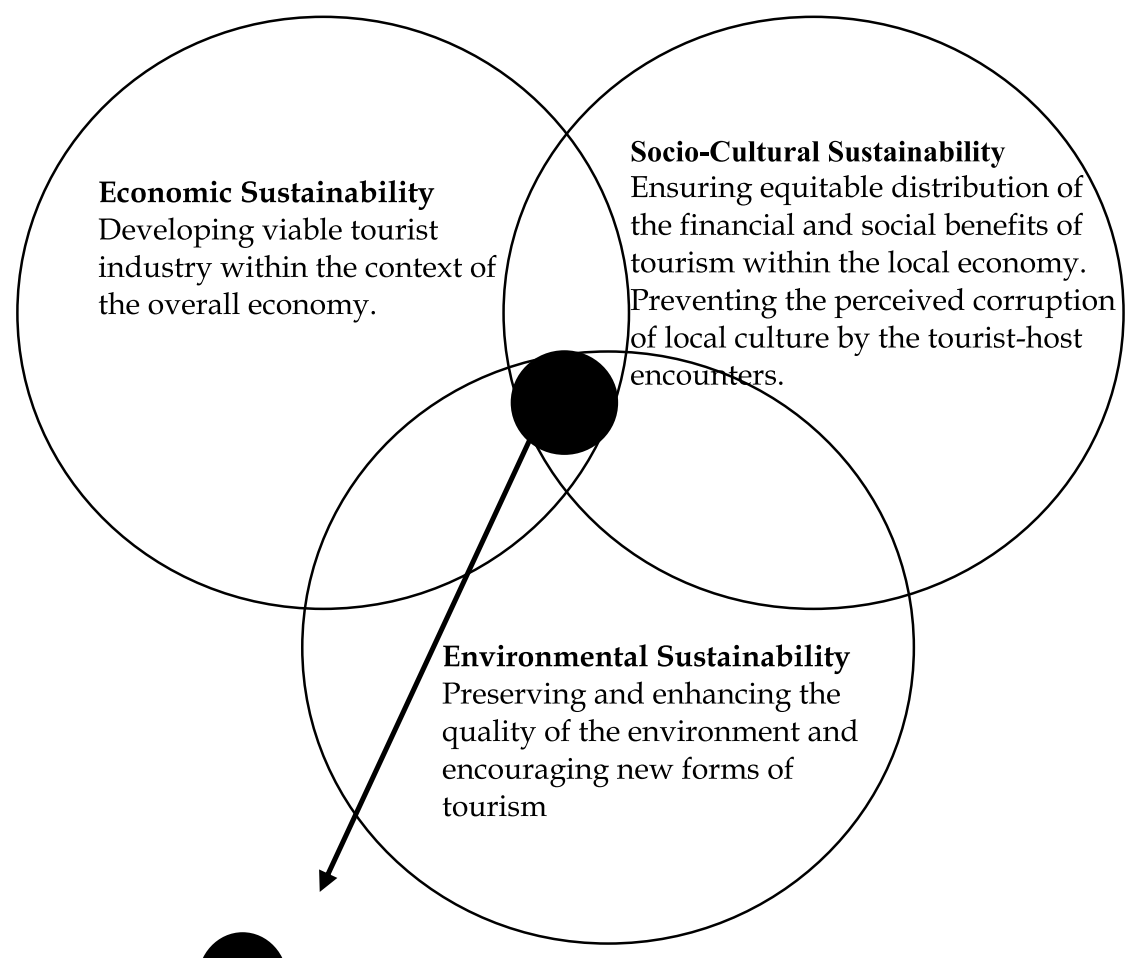

Sustainable Tourism Development.

Fig. 1. Three Dimensions of Sustainable Tourism Development (Derived from Brigiglio et al, 1996, p: 75). 
Having reviewed the literature, it can be stated that the sustainable development for tourism sector can be achieved by basing the research on the holistic understating of it, which means by taking its environmental, social and economic dimensions into consideration (Figure 1). Sustainable tourism can be achieved by improving positive impacts of tourism and eliminating the negative ones in the economic, social and physical environments of cities. Coastal cities, in particular, faced with lose of their unique natural, built environment characteristics, seasonality of jobs and over-pendency on tourism. In order to prevent and/or eliminate these negative impacts of tourism in coastal cities, it is necessary to activate sustainable tourism that means preserving and carrying the social, economic and physical structures for future with dealing with social equity, environmental preservation and economic development.

As it is clear, the two different concepts, sustainability and tourism are directly related. Accordingly, depending on the three-dimensional characteristics of them, the sustainable tourism development in a coastal city can only be possible with eliminating the negative impacts of tourism. It is possible also to say that, positive and negative impacts are also indicators of sustainable tourism.

After emphasizing the relationship between the two concepts-sustainable tourism and tourism impacts - and in respect of the stated main aim of this study, which is to assess the level of tourism impacts and to determine relationship beween tourism impacts and sustainable tourism indicators, the following text will first present detailed information on the sustainable tourism indicators, which are essential in order to set up a assessing model; following this, the model for measuring the impacts of tourism in coastal cities will be presented.

\section{Sustainable tourism indicators: Measurement}

Generally speaking, Adriaanse (1993) defines an indicator as a quantitative model and a form of information that makes a certain phenomenon perceptible that is not immediately detectable. Indicators therefore provide a simpler and more readily understand form of information than complex statistics or complex phenomena. The three main functions of indicators are: quantification, simplification and communication. Indicators also help to follow the change of phenomena in time scale and the development of phenomena in relation to the stated objects. One of the other important functions of an indicator with reference to decision-making is its potential to show the trend, i.e. the course of development, in an early stage. In order to work with indicators, one needs data, which comes from a monitoring process. Therefore, indicators should be objective and the results should be repeatable. In many cases, indicators should also be internationally comparable, although those were mainly used nationally. The main risk with regard to indicators concerns excessive simplifying and loosing of important information.

There are numerous studies on indicators, in the literature, in general and sustainability indicators in particular. For example, two scholars, Gilbert and Feenstra (1992) have, on the basis of the literature, identified four desired features of indicators:

- The indicator must be representative for the system chosen and must have a scientific basis.

- Indicators must be quantifiable. 
- A part of the cause-effect chain should be clearly represented by the indicator.

- The indicator should offer implications for policy.

According to some other scholars (Atkisson, et al.,1997; Maclaren, 1996b; Hart, 1999), good sustainability indicators should be relevant, valid, consistent, reliable, comparable, measurable and comprehensive.

Sustainable tourism indicators are tools, which could be used for sustainable tourism development. Resulting from the expansion of the notion of sustainability and the need to implement it in practice, indicators are being developed for evaluating choices which are being made during the developmental process and impacts made upon the natural and socio-economic environment. They provide a framework for evaluating existing situations, as well as, future developmental activities in the field of tourist service production (http://www.rainforest-alliance.org/programs/sv/stsc-gats-standards.pdf, WTO 2002).

Existing literature on sustainable tourism indicators (WTO, 1993; 1995) has focused on the definition / estimation of indicators for newly developed destinations. In these places sustainable tourism planning has been an issue since the very early stages of their development and the proposed indicators are defined and monitored continuously. Sustainable tourism indicators alike the sustainability indicators are about integrating tourism to its environmental and socio-cultural context (Farsari \& Prastacos, 2001).

During this research, many methods of measuring sustainability have been considered. Specialists in the area of sustainable development have developed lots of different ways in which to test sustainability (Randall, 2004; Cunningham et al. 2004). For this research, scaling technique is selected to be used for measuring sustainability. Scaling of effects addresses issues of magnitude and is based on a numerical system in which the highest number represents a very good effect and the lowest number represents a very adverse effect. The mid-point would be an average effect, or a neutral one. This can be used alone to determine some composite score for magnitude or it can be combined with a weighting scheme to incorporate considerations of importance or significance. For example, using a scale of 1 to 5 in a sustainability study, the following definitions could be applied to qualitative assessments of some activity or process:

- 1 - unsustainable in all respects

- 2 - approaching unsustainable conditions

- 3 - partially sustainable

- 4 - sustainable in most aspects

- 5 - highly sustainable

In order to develop effective, measurable and good indicators, which clearly address the sustainable tourism; it is important to recognize that these indicators need to be specific for a case study area, as Maclaren (1996) and Oktay (2005) argued. Therefore, the formulation and selection model for sustainable development indicators is necessary to develop for this purpose.

\section{Model for formulating sustainable tourism indicators}

Depending on the main argument of this research, the way of defining a set of indicators for sustainable tourism that perceive tourism in a more holistic approach, is selected to relate 
them with the negative and positive impacts of tourism activity under three dimensionsphysical, economic and social.

Based on the relationship between sustainable tourism and tourism impacts in coastal cities as discussed previously, the possible negative and positive tourism impacts on the physical, economic and social structure of a city and the indicators of environmental sustainability, economic sustainability and social sustainability need to be determined in order to achieve sustainable tourism indicators. This also will lead us to assess the level of impacts and sustainability of tourism development in coastal cities as is indicated in the model presented in Table 1.

\begin{tabular}{|c|}
\hline MODEL \\
for assessing the impacts of tourism in coastal city \\
\hline $\boldsymbol{\nabla}$ \\
\hline Analyzing the natural, built, socio-economic characteristics of the Case Study Area \\
\hline $\begin{array}{c}\text { Identifying the relevant sustainable tourism indicators/impacts from the literature } \\
\text { according to natural, built and socio-economic environment characteristics }\end{array}$ \\
\hline $\boldsymbol{\nabla}$ \\
\hline Determining the measurement units and required analysis for each selected impact \\
\hline $\boldsymbol{\nabla}$ \\
\hline Completing the Analyses in Natural, Built Environments of the Case Study Area \\
\hline $\begin{array}{c}\text { Evaluation and assessment of the impacts of tourism and/or sustainable tourism } \\
\text { indicators }\end{array}$ \\
\hline $\boldsymbol{\nabla}$ \\
\hline $\begin{array}{c}\text { Measuring the selected indicators by using scaling technique and finding out tourism } \\
\text { impacts and level of sustainability in the selected case study area. }\end{array}$ \\
\hline $\boldsymbol{\nabla}$ \\
\hline Findings and Suggestions
\end{tabular}

Table 1. Model for assessing tourism impacts.

As can be seen from the table, this model, in general terms, includes four major inter-related steps:

1. The first step is the identification of the positive and negative tourism impacts on the physical, economic and social structure of a city. They are determined with the support of literature reviews, internet and from different case studies (Table 2).

2. The second step is concerned with the identification of sustainability indicators. The suitable, measurable and accessible economic, environmental and social indicators of sustainability are selected, amongst many others. Those which can fit the above defined impacts of tourism are also taken into consideration.

3. Matching the positive and negative impacts of tourism and sustainability indicators in order to identify the indicators of sustainable tourism (see Table 3).

4. All indicators under three sub-systems (Economic, environmental, social) are separately grouped under common issues/principles, i.e. the causing factors. 


\begin{tabular}{|c|c|c|c|}
\hline & $\begin{array}{l}\text { Impacts of Tourism on the Physical } \\
\text { Environment }\end{array}$ & $\begin{array}{l}\text { Impacts of Tourism on the } \\
\text { Economy }\end{array}$ & $\begin{array}{l}\text { Impacts of Tourism on } \\
\text { Social Life }\end{array}$ \\
\hline \multirow{11}{*}{ 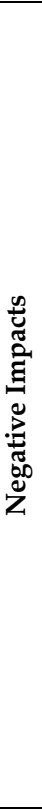 } & $\begin{array}{l}\text { Deterioration and reduction of green } \\
\text { fields }\end{array}$ & $\begin{array}{l}\text { Over-dependence on } \\
\text { tourism }\end{array}$ & $\begin{array}{l}\text { Create a degree of apathy } \\
\text { between tourists and } \\
\text { locals }\end{array}$ \\
\hline & Loss of natural landscape & $\begin{array}{l}\text { Increased inflation and } \\
\text { higher values }\end{array}$ & Congestion \\
\hline & Loss of open space & $\begin{array}{l}\text { Increased amount of import } \\
\text { (labor or goods) }\end{array}$ & Traffic jams, \\
\hline & $\begin{array}{l}\text { Sea water and air, noise, waste and } \\
\text { visual pollution }\end{array}$ & $\begin{array}{l}\text { Seasonality of production } \\
\text { and so low rate of return on } \\
\text { investment. }\end{array}$ & $\begin{array}{l}\text { Pollution (noise, air, } \\
\text { water) }\end{array}$ \\
\hline & $\begin{array}{l}\text { Size and intensity of tourism } \\
\text { development }\end{array}$ & $\begin{array}{l}\text { Creation of other costs such } \\
\text { as garbage collection and } \\
\text { disposal }\end{array}$ & Crime \\
\hline & $\begin{array}{l}\text { Demolition of the traditional } \\
\text { townscapes because of tourist facilities }\end{array}$ & & Safety \\
\hline & $\begin{array}{l}\text { Degradation of historic sites, and } \\
\text { monuments }\end{array}$ & & \\
\hline & Overpowering building size and style & & \\
\hline & $\begin{array}{l}\text { Use of inappropriate building materials } \\
\text { on external surfaces }\end{array}$ & & \\
\hline & $\begin{array}{l}\text { Obstruction of scenic view by } \\
\text { development }\end{array}$ & & \\
\hline & Insufficient Planning Controls & & \\
\hline \multirow{9}{*}{ 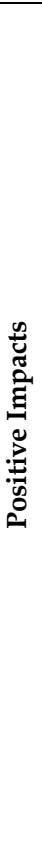 } & Conservation of natural green areas & $\begin{array}{l}\text { Development of leisure } \\
\text { activities, }\end{array}$ & $\begin{array}{l}\text { Improvement of local } \\
\text { public services }\end{array}$ \\
\hline & $\begin{array}{l}\text { Improvement in quality of } \\
\text { environment }\end{array}$ & $\begin{array}{l}\text { Development of cultural } \\
\text { awareness }\end{array}$ & Increased cultural activity \\
\hline & $\begin{array}{l}\text { Improvement in public awareness of } \\
\text { environmental issues }\end{array}$ & Providing employment & $\begin{array}{l}\text { Alteration to some aspects } \\
\text { of traditional culture }\end{array}$ \\
\hline & $\begin{array}{l}\text { Conservation of the historical and } \\
\text { cultural heritage }\end{array}$ & Enhancing income level & $\begin{array}{l}\text { Re-ceration and } \\
\text { preservation of the } \\
\text { identity of local culture }\end{array}$ \\
\hline & Restoration of the old fabric & $\begin{array}{l}\text { Reduction of } \\
\text { unemployment }\end{array}$ & Improve quality of life \\
\hline & $\begin{array}{l}\text { Number/ Ratio of preserved } \\
\text { traditional building typology }\end{array}$ & Increased standard of living & $\begin{array}{l}\text { Introduce the benefits of } \\
\text { interactions between } \\
\text { people of different } \\
\text { cultural } \\
\text { backgrounds }\end{array}$ \\
\hline & $\begin{array}{l}\text { Improvement of the area's appearance } \\
\text { (visual, architectural and aesthetic) }\end{array}$ & $\begin{array}{l}\text { Affordable price of goods } \\
\text { and services }\end{array}$ & \\
\hline & Restrict and control traffic & $\begin{array}{l}\text { Cost of land and housing } \\
\text { Cost of living }\end{array}$ & \\
\hline & $\begin{array}{l}\text { Development of an infrastructure such } \\
\text { as transport, road maintenance, } \\
\text { organizing parking areas }\end{array}$ & $\begin{array}{l}\text { Development and } \\
\text { maintenance of the } \\
\text { infrastructure and } \\
\text { resources }\end{array}$ & \\
\hline
\end{tabular}

Table 2. List of tourism impacts (developed from literature review). 


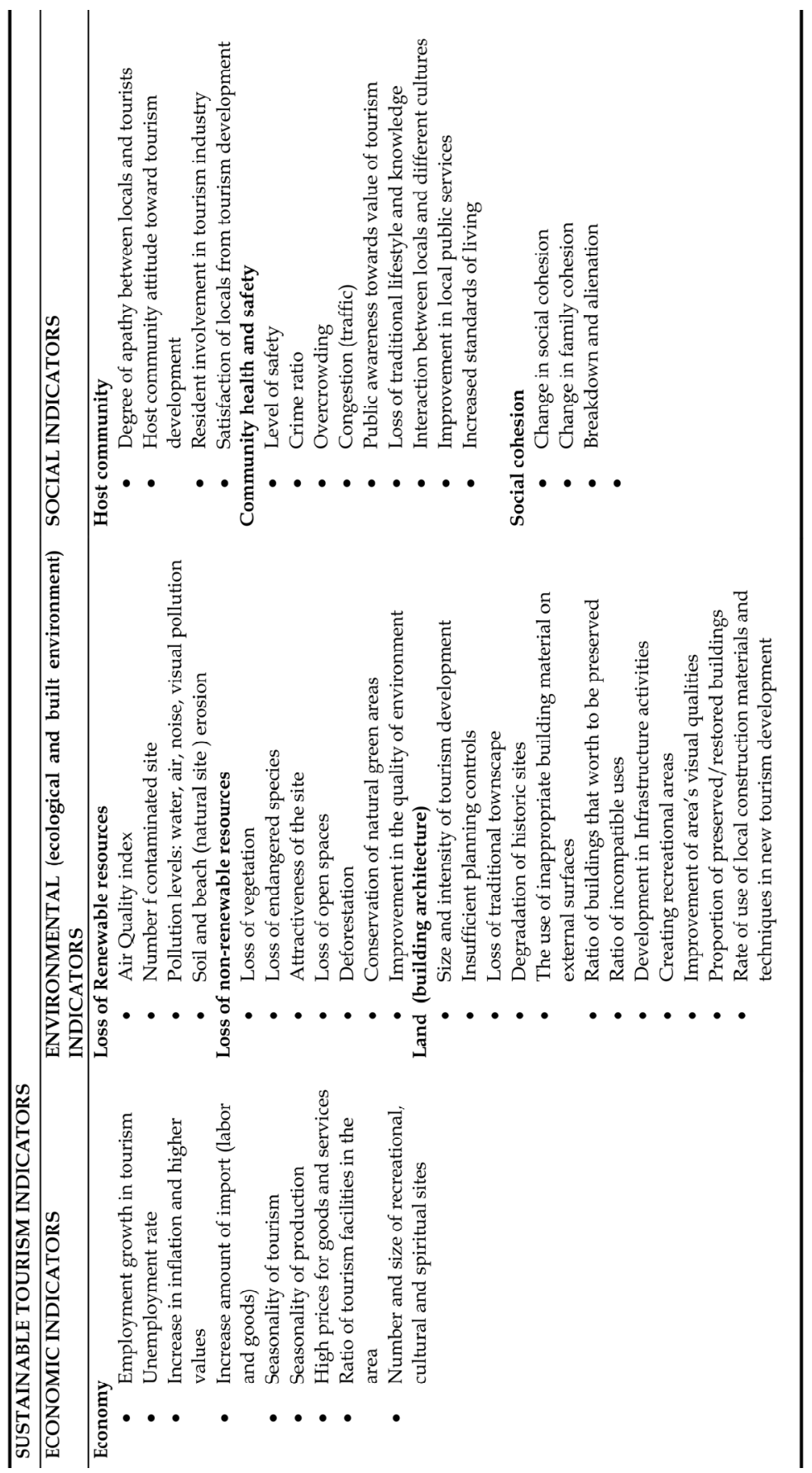

Table 3. Sustainable tourism indicators. 


\begin{tabular}{|c|c|c|}
\hline $\begin{array}{l}\text { Negative Impacts of } \\
\text { Tourism on the Built } \\
\text { Environment }\end{array}$ & Measurement Units & Required Analysis \\
\hline $\begin{array}{l}\text { Size and intensity of } \\
\text { tourism development }\end{array}$ & $\begin{array}{l}\text { Form and size of tourism } \\
\text { buildings }\end{array}$ & \begin{tabular}{|l} 
Statistical documents, \\
Architectural evaluation, \\
Silhouette, figure ground \\
analysis and Observation
\end{tabular} \\
\hline $\begin{array}{l}\text { Demolition of the } \\
\text { traditional townscapes } \\
\text { because of tourist } \\
\text { facilities }\end{array}$ & $\begin{array}{l}\text { Form, details and size of } \\
\text { poorly designed buildings }\end{array}$ & $\begin{array}{l}\text { Silhouette and Figure ground } \\
\text { and Building height analysis }\end{array}$ \\
\hline $\begin{array}{l}\text { Degradation of historic } \\
\text { sites, and monuments }\end{array}$ & $\begin{array}{l}\text { Degraded buildings as a } \\
\text { percentage of total urban } \\
\text { surface area }(\%)\end{array}$ & Land use analysis \\
\hline $\begin{array}{l}\text { Overpowering building } \\
\text { size and style }\end{array}$ & $\begin{array}{l}\text { Number of overpowering } \\
\text { tourisms buildings as a } \\
\text { percentage of total urban } \\
\text { surface area }(\%)\end{array}$ & $\begin{array}{l}\text { Silhouette and Urban Pattern } \\
\text { Analysis }\end{array}$ \\
\hline $\begin{array}{l}\text { Use of inappropriate } \\
\text { building materials on } \\
\text { external surfaces } \\
\end{array}$ & $\begin{array}{l}\begin{array}{l}\text { Existence of inappropriate } \\
\text { building materials, and details } \\
\text { on the façades }\end{array} \\
\end{array}$ & $\begin{array}{l}\text { Architectural Evaluation } \\
\text { (Façade analysis) and } \\
\text { observation }\end{array}$ \\
\hline $\begin{array}{l}\text { Obstruction of scenic } \\
\text { view by development }\end{array}$ & $\begin{array}{l}\text { Number of inhuman scaled } \\
\text { and bulk sized buildings along } \\
\text { the shoreline and around the } \\
\text { existing environment }\end{array}$ & $\begin{array}{l}\text { Figure-ground, Silhouette } \\
\text { analysis, building heights and } \\
\text { observation }\end{array}$ \\
\hline $\begin{array}{l}\text { Insufficient Planning } \\
\text { Controls }\end{array}$ & $\begin{array}{l}\text { Effects of legislation and } \\
\text { planning controls }\end{array}$ & Existing laws and regulations \\
\hline $\begin{array}{l}\text { Positive Impacts of } \\
\text { Tourism on the Built } \\
\text { Environment }\end{array}$ & Measurements Units & Required Analysis \\
\hline $\begin{array}{l}\text { Conservation of the } \\
\text { historical and cultural } \\
\text { heritage }\end{array}$ & $\begin{array}{l}\text { Conserved historic buildings } \\
\text { as a } \\
\text { percentage of total urban } \\
\text { surface area }(\%)\end{array}$ & Listed Building Analysis \\
\hline $\begin{array}{l}\text { Restoration of the old } \\
\text { fabric }\end{array}$ & $\begin{array}{l}\text { Preserved restored buildings } \\
\text { as a percentage of total urban } \\
\text { surface area }(\%)\end{array}$ & Land use survey \\
\hline $\begin{array}{l}\text { Number/ Ratio of } \\
\text { preserved traditional } \\
\text { building typology } \\
\end{array}$ & $\begin{array}{l}\text { Preserved traditional buildings } \\
\text { as a percentage of total urban } \\
\text { surface area }(\%)\end{array}$ & $\begin{array}{l}\text { Structural Condition and Façade } \\
\text { Analysis, Listed building } \\
\text { analysis }\end{array}$ \\
\hline $\begin{array}{l}\text { Improvement of the area's } \\
\text { appearance (visual, } \\
\text { architectural and } \\
\text { aesthetic) }\end{array}$ & $\begin{array}{l}\text { Details, heights and form of } \\
\text { the existing urban pattern }\end{array}$ & $\begin{array}{l}\text { Silhouette and Architectural } \\
\text { Evaluation Analysis }\end{array}$ \\
\hline
\end{tabular}




\begin{tabular}{|l|l|l|}
\hline Restrict and control traffic & $\begin{array}{l}\text { Mode of transportation in the } \\
\text { case study area }\end{array}$ & Traffic Analysis \\
\hline $\begin{array}{l}\text { Development of an } \\
\text { infrastructure such as } \\
\text { transport, road } \\
\text { maintenance, organizing } \\
\text { parking areas }\end{array}$ & $\begin{array}{l}\text { Improvement in water, } \\
\text { electricity, drainage and } \\
\text { telephone systems }\end{array}$ & Observations \\
\hline
\end{tabular}

Table 4. The measurement units and required analysis for each selected negative and positive impacts of tourism on the built environment.

After having a sustainable tourism indicator list based on the above mentioned method, there is need for determining, selecting the relevant indicators for each case area. Since each of the case study areas has different natural, built and socio-cultural characteristics, some of the already determined impacts (indicators) from the available literature cannot be relevant for them; in other words, indicators of the positive and negative impacts need to be sitespecific before determining the tourism impacts. Accordingly, the relevant impacts (indicators) should be determined for the selected area. Keeping this in mind, a model has been developed, which is composed of several steps (Table 4):

a. determination of the physical and socio-economic characteristics of a case study area;

b. identification and selection (determination) of the relevant sustainable tourism indicators in accordance with the physical, economic and social characteristics of case areas;

c. identification of means of assessment and required analysis methods for each indicators (Table 4 );

d. application of the analyses in three dimensions of case study areas;

e. evaluation and assessment of the impacts of tourism and/or sustainable tourism indicators on the case study areas

f. Measuring the selected indicators by using scaling technique and finding out the level of sustainability in the selected case study area.

g. presentation of findings and suggestions for decreasing the negative impacts and encouraging the positive impacts.

After completing the analyses and applying scaling techniques for each impacts in three structures of a coastal city, the positive and negative impacts of tourism and as well as the level of sustainable tourism development in a coastal areas can be achieved. In the conclusion part of this study, the proposals will be discussed in order to prove this relation and to have more sustainable coastal cities.

\section{Conclusion}

This research has set out a theoretical framework based on the inter-related concepts and approach of "tourism impacts and sustainability", and it has used these concepts to propose a model for measuring the level of sustainable tourism in coastal cities.

In setting out to test the applicability of this approach in measuring the sustainability of tourism development in any urban area, it is stated that each case study site needs to have different set of indicators according to the differences in their geographic, economic, social 
and environmental structures. In due course, indicators may vary in their relevance according to the local environment and the final purpose of their measurement and monitoring.

This research has also indicated that there is direct relationship between tourism impacts and the level of sustainability in the structures of a particular area. Based on this argument, successful, long-term and sustainable tourism development in coastal cities can only be achieved by eliminating the negative impacts of tourism. This also can be said in a way that, when the level of sustainability is high in any one of these three structures-economic, environment, social - it means the level of negative impacts is low in the same structures of a coastal city. In other words, if the physical environment of a coastal city has affected by the negative impacts of tourism, the result of this paper leads us to say that, the physical structure of a coastal city might be in unsustainable conditions.

\section{References}

Adriaanse A. 1993. Environmental policy performance indicators: a study of the development of indicators for environmental policy in the Netherlands. The Hauge: SDU Publishers. 175pp.

Akis, S., Peristianis, N., \& Warner, J. (1996). Residents' attitudes to tourism development: The case of Cyprus. Tourism Management, 17(7), 481$\} 494$.

Ashworth GJ, Goodal B. (1990) Marketing Tourism Places. Routledge, London and New York.

Atkinson, A., Balakrishnan, P, Booth, J., Cote, T., Groot, T. and Malmi, H. (1997). New directions in management accounting research. Journal of Management Accounting Research, 9 , pp. 70-108.

Briguglio, L., Archer, B., Jafari, J. and Wall G. (eds) (1996) Sustainable Tourism in Islands and Small States: Issues and Policies. Pinter.

Calvia Declaration on Tourism and Sustainable Development in the Mediterranean (1997). International Conference on Tourism and Sustainable Development, Calvia (Mallorca),April. http://www.econtur.de/la21calvia.htm.

Coccossis H \& Nijkamp P (1995) Sustainable Tourism Development Ashgate.

Cooper, C., Fletcher, J., Gilbert, D. , Shepherd, R. and Wanhill, S. (1998), Tourism Principles and Practice, 2nd edition. Addison Wesley Longman Publishing, New York: 40-46.

Cunningham, B., Battersby, N., Wehrmeyer, W., and Fothergill, C. (2004) A Sustainability Assessment of a Biolubricant, Journal of Industrial Ecology 7, 3-4, p.179-192.

Davis, D, J. Allen, R.M. Consenza (1988) Segmenting Local Residents by Their Attitudes, Interests and Opinions Toward Tourism; Journal of Travel Research 27(2), pp 2-8.

Doxey, G. V. (1975). A causation theory of visitor-resident irritants methodology and research inferences, in the Sixth Annual Conference, Proceedings of Travel Research Association.

Farsari, Y. and Prastacos,P. (2001). Sustainable tourism indicators for Mediterranean established destinations. Tourism Today, 1 (1), pp.103-121 
Gartner, WC (1996) Tourism Development: Principles, Process and Policies. Van Nostrand Reinhold, ITP, International Thompson Publishing, London.

Gilbert, A.J. and Feenstra, J.F. (1992) A sustainability indicator for the Dutch environmental policy theme "Diffusion": cadmium accumulation in soil. Ecological Economics, 9.253-265.

Gunn, C. A. (1988). Tourism planning. New York: Taylor \& Francis.

Hart, M. (1999) Guide to Sustainable Community Indicators. North Andover, MA: Hart Environmental Data.

Inskeep, E. (1991) Tourism Planning: An Integrated and Sustainable Development Approach. New York, Van Nostrand Reinhold. Johnson et al., 1994

Johnson, J. D., Snepenger, D. J. \& Akis, S. (1994) Residents' perceptions of tourism development, Annals of Tourism Research, 21, pp. 629-642.

Jurowski, C., Uysal, M., \& Williams, D. R. (1997). A theoretical analysis of host community resident reactions to tourism. Journal of Travel Research, 36(2), 3\}11.

Keogh (1990) B. Public participation in community tourism planning, Annals of Tourism Research 17 (1990) (3), pp. 449-465.

Liu, JC and Var, T (1986) Residents Attitude Toward Tourism Impacts in Hawaii. Annals of Travel Research, 13, pp.193-214.

MacLeren, VV. (1996) Urban Sustainability Reporting. Journal of the American Planning Association. Vol. 62, no. 2, Spring, pp. 184-203

Mathieson, A. and Wall, G. (1982) Tourism: Economic, Physical and Social Impacts. UK, Longman Group.

McCool, S. F., \& Martin, S. T. (1994). Community attachment and attitudes toward tourism development. Journal of Travel Research,32(3), 29$\} 34$.

Milman, A and Pizam, A (1988) Social Impacts of Tourism on Central Florida; Annals of Tourism Research, 15(2), pp. 191-204.

Murphy, P.E. (1985) Tourism: A Community Approach. Routledge, New York.

Oktay, B. (2005) A Model for Measuring the Level of Sustainability of Historic Urban quarters: Comparative Case Studies of Kyrenia and Famagusta in North Cyprus. Unpublished PhD Thesis. Eastern Mediterranean University, Famagusta, North Cyprus.

Pearce,D. (1989). Tourist development, Longman, London.

Perdue, R. R., Long, P. T., \& Allen, L. (1987). Rural resident tourism perceptions and attitudes. Annals of Tourism Research, 14, 420-429.

Randall, S. (available in 2006) The Sustainable Development of Oxford City. [Online].Available: //www.brookes.ac.uk/schools/rem/dissertations/2000/sarah_randal.html.

Rogers, M.F. \& Collins, Y.M.T. (2001). The Future of Australia's Country Towns, Centre for Sustainable Regional Communities, La Trobe University, Melbourne.

Swarbrooke, J. (1998). “Sustainable Tourism Management." New York: CABI Publishing

UN, (2001). Sustainable Development of Tourism. Report of the Secretary General.United Nations, New York.

UNEP \& WTO (1998). Guide for Local Authorities on Developing Sustainable Tourism. UNWTO. Madrid. 194. 
Wahab, S; Pigram, J.(1997) Tourism, Development and Growth: The Challenge of Sustainability Routledge

WCED. (1987). Our common future. Oxford: Oxford University Press.

WTO (1993). Indicators for the sustainable management of tourism. Report of the international working group on indicators of sustainable tourism to the environment committee. International Institute for Sustainable Development, Winnipeg, Canada.

WTO (1998) Guide for Local Authorities on Developing Sustainable Tourism. http://www.world-tourism.org/cgi-bin/infoshop.storefront/ EN/product/1016-1.

http://www.rainforest-alliance.org/programs/sv/stsc-gats-standards.pdf, WTO 2002 


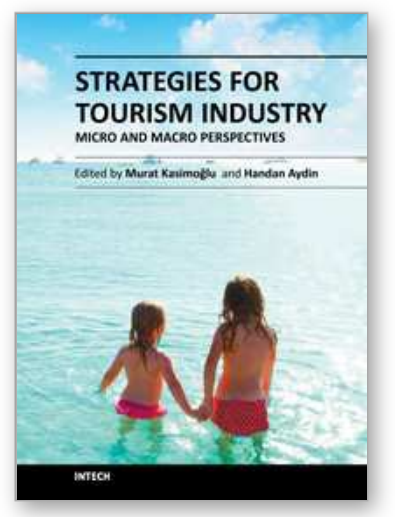

\author{
Strategies for Tourism Industry - Micro and Macro Perspectives \\ Edited by Dr. Murat Kasimoglu
}

ISBN 978-953-51-0566-4

Hard cover, 392 pages

Publisher InTech

Published online 20, April, 2012

Published in print edition April, 2012

Today, it is considered good business practice for tourism industries to support their micro and macro environment by means of strategic perspectives. This is necessary because we cannot contemplate companies existing without their environment. If companies do not involve themselves in such undertakings, they are in danger of isolating themselves from the shareholder. That, in turn, creates a problem for mobilizing new ideas and receiving feedback from their environment. In this respect, the contributions of academics from international level together with the private sector and business managers are eagerly awaited on topics and sub-topics within Strategies for Tourism Industry - Micro and Macro Perspectives.

\title{
How to reference
}

In order to correctly reference this scholarly work, feel free to copy and paste the following:

Beser Oktay Vehbi (2012). A Model for Assessing the Level of Tourism Impacts and Sustainability of Coastal Cities, Strategies for Tourism Industry - Micro and Macro Perspectives, Dr. Murat Kasimoglu (Ed.), ISBN: 978953-51-0566-4, InTech, Available from: http://www.intechopen.com/books/strategies-for-tourism-industrymicro-and-macro-perspectives/a-model-for-assessing-the-level-of-tourism-impacts-and-sustainability-ofcoastal-cities

\section{INTECH}

open science | open minds

\section{InTech Europe}

University Campus STeP Ri

Slavka Krautzeka 83/A

51000 Rijeka, Croatia

Phone: +385 (51) 770447

Fax: +385 (51) 686166

www.intechopen.com

\section{InTech China}

Unit 405, Office Block, Hotel Equatorial Shanghai

No.65, Yan An Road (West), Shanghai, 200040, China

中国上海市延安西路65号上海国际贵都大饭店办公楼405单元

Phone: +86-21-62489820

Fax: +86-21-62489821 
(C) 2012 The Author(s). Licensee IntechOpen. This is an open access article distributed under the terms of the Creative Commons Attribution 3.0 License, which permits unrestricted use, distribution, and reproduction in any medium, provided the original work is properly cited. 